Review

\title{
Functional Significance of the Adcy10-Dependent Intracellular cAMP Compartments
}

\author{
Sofya Pozdniakova ${ }^{1,2, *}$ and Yury Ladilov ${ }^{1,2}$ \\ 1 Institute of Gender in Medicine, Center for Cardiovascular Research, Charite, 10115 Berlin, Germany; \\ yury.ladilov@charite.de \\ 2 DZHK (German Center for Cardiovascular Research), Berlin Partner Site, 10115 Berlin, Germany \\ * Correspondence: sofyapozdniakova@gmail.com
}

Received: 5 March 2018; Accepted: 9 May 2018; Published: 11 May 2018

\begin{abstract}
Mounting evidence confirms the compartmentalized structure of evolutionarily conserved $3^{\prime}-5^{\prime}$-cyclic adenosine monophosphate (cAMP) signaling, which allows for simultaneous participation in a wide variety of physiological functions and ensures specificity, selectivity and signal strength. One important player in cAMP signaling is soluble adenylyl cyclase (sAC). The intracellular localization of SAC allows for the formation of unique intracellular cAMP microdomains that control various physiological and pathological processes. This review is focused on the functional role of sAC-produced cAMP. In particular, we examine the role of sAC-cAMP in different cellular compartments, such as cytosol, nucleus and mitochondria.
\end{abstract}

Keywords: adcy10; cAMP; phosphodiesterase; compartmentalization

\section{Introduction}

Even though $3^{\prime}-5^{\prime}$-cyclic adenosine monophosphate (cAMP) was discovered more than half a century ago, it still remains an object of scientific interest. cAMP signaling plays an important role in a wide variety of physiological processes: transcription regulation [1,2], metabolism [3,4], cell migration [5,6], mitochondrial homeostasis [7-11] (reviewed in Reference [12]), as well as cell proliferation [13] (reviewed in Reference [14]) and cell death [15] (reviewed in Reference [16]). The importance of cAMP signaling is underlined by the fact that this pathway is evolutionarily conserved and can be found in all species from microorganisms to mammals [17-19].

There are two main sources of cAMP in the cell: Transmembrane (tmAC) and intracellularly localized soluble adenylyl cyclases (sAC). In mammalian cells, nine genes encode tmAC and one gene encodes SAC. The structural organization of tmAC is common for all members of this subfamily (9 tmAC) and the activity of tmAC is controlled by hormones and neurotransmitters [20,21]. Two important properties characterize the principal difference between tmAC and sAC: First, Gs, Gi, $\mathrm{G} \alpha \mathrm{i} / \mathrm{o}, \mathrm{G} \beta \gamma$ and Gq proteins regulate tmAC activity [22,23], whereas sAC activity is regulated by bicarbonate [24]; second, tmAC's localization is restricted to the plasma membrane, while sAC is widely distributed within the cell and organelles [25]. The distinct spatial distribution of the two main cAMP sources leads to the formation of multiple intracellular cAMP compartments, thereby enabling the specificity and selectivity of cAMP signaling.

The specificity of cAMP signaling is further achieved through the restriction of cAMP diffusion due to physical barriers, i.e., mitochondria [26], and phosphodiesterases (PDEs) [27-29]. Therefore, with the exception of a rare internalization of tmAC [30], cAMP produced by tmAC under physiological conditions is mainly localized close to the plasma membrane. In contrast, sAC builds cAMP pools within various cellular compartments, e.g., cytosol, mitochondria, nucleus or the subplasmalemmal 
compartment [31-33]. In this review, we focus on sAC-dependent cAMP signaling, with a particular focus on its role in mitochondrial biology.

\section{Structure and Regulation of sAC Activity}

\subsection{Structure}

Mammalian SAC shows structural and functional similarities with cyanobacterial sAC [24], which argues for a bacterial origin of mammalian SAC that has been strongly conserved throughout the process of evolution [34]. The structure of the sAC catalytic core has a typical Class III pseudo-heterodimer arrangement of structurally similar $C_{1}$ (residues 34-219) and $C_{2}$ (residues 288-463) domains positioned at the $\mathrm{N}$-terminus and connected by a linker [35]. The $\mathrm{C}$-terminal region of sAC starts with a small motive, mediating auto-inhibitory effect [36], that most likely acts together with the neighboring putative NTPase domain [37]. Additionally, the C-terminal region contains a heme-binding domain that can bind nitric oxide (NO), carbon monoxide, and other potential gaseous signaling molecules [38]. Active cyclase is a heterodimer of two catalytic domains [19]. sAC is encoded by a single functional sAC gene in the human genome ( $A D C Y 10)$, comprising of 33 exons covering approximately $104 \mathrm{~kb}$ of genomic DNA [39,40]. sAC mRNA undergoes extensive alternative splicing which leads to smaller splice variants [41]. In mammalian cells the predominant isoform is a $50 \mathrm{kDa}$ truncated $\mathrm{sAC}\left(\mathrm{sAC}_{\mathrm{t}}\right)$ which is categorized as a splice variant of the full-length enzyme. $\mathrm{sAC}_{\mathrm{t}}$ is restricted to the N-terminal part of the full-length protein covering $C_{1}$ and $C_{2}$ [42]. sAC $C_{t}$ shows a higher activity than the full-length enzyme, as the activity of the latter is suppressed by the small auto-inhibitory module at the C-terminal [36]. More splice sAC variants have also been identified in human somatic tissue. These isoforms predominantly consist of $C_{2}$ domain and require a partner protein to become active due to a missing or incomplete $C_{1}$ domain $[19,43]$.

\subsection{Posttranslational Regulation of $S A C$}

$\mathrm{sAC}$ is insensitive to heterotrimeric G-protein regulation due to a missing or modified $\mathrm{G}_{\mathrm{s} \alpha}$ and $\mathrm{G}_{B \gamma}$ binding region, which is important for the activation of tmAC [44]. A recent study performed by Hebert-Chatelain et al., however, challenged this paradigm of sAC insensitivity to G proteins. The authors demonstrated that the activation of mitochondrial $G_{\alpha i}$ proteins through cannabinoid receptors inhibits mitochondrial sAC [45]. However, the authors investigated the role of sAC applying the sAC inhibitor KH7, which may have also led to sAC-independent effects on the mitochondria $[9,46]$. The results could also be explained by an indirect downregulation of sAC activity.

sAC activity requires divalent metal cations in the catalytic active site of the enzyme in order to coordinate the binding and cyclizing of ATP. SAC is most active in the presence of $\mathrm{Mn}^{2+}$, however it is not clear whether the physiological intracellular $\mathrm{Mn}^{2+}$ concentration would support sAC activity [47]. $\mathrm{Mg}^{2+}$ and $\mathrm{Ca}^{2+}$ concentrations within the expected intracellular range 1-10 mmol/L for $\mathrm{Mg}^{2+}$ and 2-1200 nmol/L for $\mathrm{Ca}^{2+}$ make significant contributions to the regulation of sAC activity [43]. Furthermore, sAC serves as an intracellular ATP sensor because its activity is dependent on physiological changes in ATP concentrations. When the ATP level is reduced, sAC shows decreased activity due to substrate limitation [48].

A unique property of sAC is its activation through bicarbonate binding, which makes sAC the only protein with enzymatic activity regulated by bicarbonate. Bicarbonate directly binds to and activates sAC in a $\mathrm{pH}$-independent manner [24]. The $\mathrm{EC}_{50}$ for the bicarbonate stimulation of mammalian sAC is within the 10-25 mmol/L range, which is appropriate for sensing physiological bicarbonate levels of $2-25 \mathrm{mmol} / \mathrm{L}$ [24]. It is also worth mentioning that sAC activity increases synergistically in the presence of bicarbonate and $\mathrm{Ca}^{2+}[43,49]$. 


\subsection{Pharmacological Regulation of $s A C$}

sAC is involved in a wide variety of physiological processes, including metabolism, proliferation, apoptosis, differentiation, migration development, ion transport, $\mathrm{pH}$ regulation and gene expression (reviewed in [16,47]). It is also involved in different pathologies such as hyperproliferative skin disease, hypercalciuria, type 2 diabetes glaucoma and prostate cancer [40,50-55]. Therefore, the pharmacological inhibition or activation of sAC may be considered for the treatment of the pathologies and the maintenance of the physiological processes mentioned above. Although the search for potential sAC activators remains unsuccessful, several inhibitors have been discovered. Catechol estrogens (CEs) are physiologically occurring steroid derivatives that can inhibit mammalian AC enzymes. 2-hydroxy estradiol (2-CE) and 4-hydroxy estradiol (4-CE) inhibit purified mammalian SAC (IC $502-8 \mu \mathrm{mol} / \mathrm{L}$ ) as well as some purified tmAC isoforms with comparable potency [44,56]. CEs are postulated to be non-competitive inhibitors of AC that bind to a pocket near the enzyme's active site [57].

Another potent sAC inhibitor is (E)-2-(1H-Benzo[d]imidazol-2-ylthio)- $N^{\prime}-(5-b r o m o-2-$ hydroxybenzylidene) propanehydrazide (KH7) $\left(\mathrm{IC}_{50} \sim 3 \mu \mathrm{mol} / \mathrm{L}\right)$ [58]. KH7 shows good membrane permeability and has no significant effect on tmACs, GC or PDEs up to a concentration of $100 \mu \mathrm{mol} / \mathrm{L}$ [56]. KH7 has been used as a pharmacological tool in a large number of studies and seems to be a promising compound for drug development. Unfortunately, KH7 exhibits an intrinsic fluorescence and is therefore of limited use when studies involve fluorescence-based live cell cAMP sensors, according to our own observations and research [9]. In addition, KH7 leads to mitochondrial uncoupling in a sAC-independent manner $[9,46]$. Therefore, KH7 use should be restricted to short-term assays and the results should be interpreted carefully.

Recently, LRE1—an improved sAC-specific inhibitor-has been identified [46]. LRE1 inhibits SAC by occupying the bicarbonate binding site. LRE1 neither exhibits cell toxicity nor results in uncoupling of isolated brain mitochondria [46]. In our experiments, we have not observed any interference between LRE1 and fluorescence, which allows the compound to be used in live cell imaging.

\section{Functional Role of sAC in Different Cellular Compartments}

sAC-generated cAMP is involved in the regulation of multiple cellular functions as it is generated locally within particular microdomains containing cAMP effectors (PKA, EPAC, cyclic nucleotide-gated ion channels and Popeye domain-containing proteins [59-62]), scaffolding proteins (A-kinase anchoring proteins, AKAPs) and a subset of PDEs, that degrade cAMP, and thus suppress cAMP diffusion $[28,29,63]$. AKAPs form the complexes of cAMP and its downstream targets, and bind these complexes to particular subcellular compartments [22]. Tight spatiotemporal regulation of cAMP dynamics inside discrete signaling compartments provides specific responses to diverse stimuli at certain locations and avoids unregulated cross-communication between microdomains.

Mammalian SAC is distributed over different compartments throughout the cell: the cytosol, nucleus, plasma membrane and mitochondria [25,64-68]. Although numerous cellular functions have been attributed to the activity of SAC, the functional significance of SAC in particular compartments is still in need of clarification. Therefore, in this review, the functional significance of different sAC domains will be described according to the sAC subcellular localization (Figure 1). 


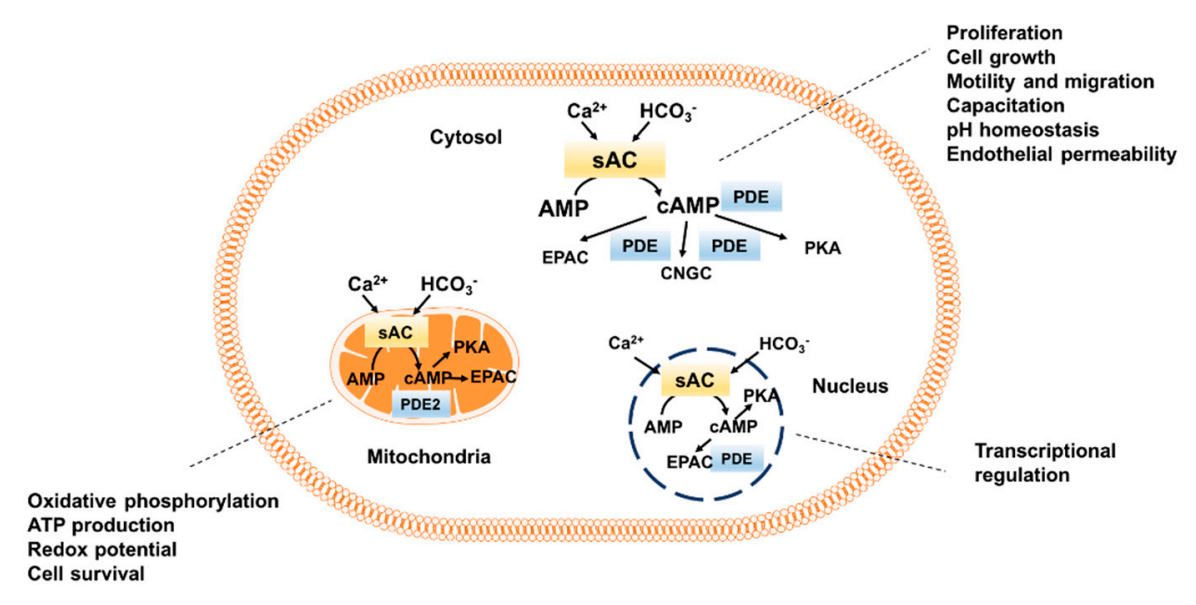

Figure 1. Intracellular distribution of sAC-dependent cAMP pool. sAC, soluble adenylyl cyclase; PKA, protein kinase A, EPAC, exchange protein directly activated by CAMP; CNGC, cyclic nucleotide gated channels; PDE, phosphodiesterase.

\subsection{Role of sAC-Dependent cAMP Signaling in Microtubules and Centrioles}

It has been suggested that SAC both co-localizes with microtubules and centrioles, while also playing a role in mitosis and cytokinesis [25]. During prophase, sAC is dispersed from the nucleus. In metaphase and anaphase, it accumulates at the mitotic poles and spindle fibers. During cytokinesis, sAC is localized in the midbody. In the centrioles, the main pathway that promotes the phosphorylation cascade is PKA-dependent, whereas in the microtubules it is EPAC-dependent [25].

\subsection{Role of Cytosolic/Nuclear sAC-Dependent cAMP Signaling}

\subsubsection{Proliferation and Cell Growth}

Cytosolic sAC makes a significant contribution to the regulation of cell growth, particularly in hyperplasia [16]. In prostate carcinoma tissue and cells (LNCaP, PC3), sAC was shown to be overexpressed and the suppression of sAC activity significantly reduced the proliferation rate [53]. A subsequent analysis of the underlying cellular mechanisms revealed the role of the EPAC/Rap1/B-Raf axis in the sAC-dependent regulation of cell growth. Inhibiting sAC down regulates cyclin $B_{1}$ and cyclin-dependent kinase 1 , which are the key proteins involved in the $G 2 / M$ transition. Thus, sAC suppression causes cell cycle arrest in the G2 phase [53]. In another tumor cell line (PC12), nerve growth factor stimulation via sAC was shown to induce cAMP elevation, which, in turn, promoted the activation of Rap1 [69]. This mechanism is considered to be implicated in the process of brain-derived neurotrophic factor-mediated axonal guidance. A study performed in breast cancer cells postulated that SAC in the EPAC-Rap1 dependent mechanism is involved in a metabolic switch, thereby favoring the development of malignant progression [70].

sAC also plays a role in non-proliferative cell growth, i.e., hypertrophy. It is expressed in embryonic neurons and generates CAMP in response to netrin-1, a member of the laminin-related secreted proteins family, thus affecting axon outgrowth [71]. Moreover, retinal ganglion cell survival and axon growth is regulated by $\mathrm{Ca}^{2+}$-dependent cAMP-PKA signaling [64]. Our recent study revealed a novel role for SAC in cardiac hypertrophy induced by either $\beta$-adrenergic stimulation or pressure overload [72]. B-Raf's involvement in sAC-dependent hypertrophy was also demonstrated in that study.

\subsubsection{Motility}

sAC plays a central role in sperm physiology [58,73]. During one of the first definable events in capacitation, $\mathrm{Ca}^{2+}$ and bicarbonate enter into sperm and activate SAC to produce cAMP. This 
promotes an asymmetrical flagellar beat frequency and results in vigorous forward sperm motility [47]. In keeping with this role of sAC in sperm motility, male sAC knockout mice show an infertility phenotype [74]. Though sAC's role in cell motility was initially exclusively considered for sperm, a recent report suggested that $\mathrm{SAC}$ is also involved in the regulation of leukocyte trans-endothelial migration through the CD99 [75]. CD99 and sAC are co-localized in a signaling complex with ezrin and PKA. The stimulation of CD99 promotes the sAC-PKA pathway that activates membrane trafficking from the lateral border recycling compartment to sites of trans-endothelial migration, facilitating the passage of leukocytes across the endothelium [75].

\subsection{3. $\mathrm{pH}$ Homeostasis}

sAC plays an important role in the regulation of $\mathrm{pH}$ homeostasis [76,77]. In epididymal clear cells and in kidney intercalated cells, sAC-produced cAMP promotes the translocation of the vacuolar proton pumping ATPase (V-ATPase) to the acid-secreting surface in a PKA-dependent manner [78,79]. The apical translocation of V-ATPase, associated with the protein activation, plays an important role in the regulation of $\mathrm{pH}$ homeostasis and extracellular acidification/alkalinization. The maintenance of acid/base balance is important for the regulation of acids in the body. V-ATPase dysfunction is one of the factor that leads to renal distal tubular acidosis, the formation of kidney stones and proteinuria [80].

Recently, sAC's control of the endosomal-lysosomal acidification has been shown to function in a PKA-dependent manner. The absence of sAC disrupts V-ATPase localization at the lysosomal membrane which is rescued by treatment with membrane-permeable cAMP [81]. It is interesting to note that a disturbance in lysosomal acidification through sAC knockout leads to an impaired autophagic degradative system.

\subsubsection{Transcriptional Regulation}

An increasing number of reports argue for the essential role of sAC in regulating the transcriptional activity of the cell. Indeed, sAC has been identified as a unique source of cAMP in the nucleus that in PKA-dependent manner regulates CREB activity [68]. sAC, in a PKA-dependent manner, is especially involved in corticotropin-releasing hormone-mediated CREB phosphorylation and c-fos (endogenous CREB target) induction in hippocampal neuronal cells [82]. A recent study demonstrated that sAC contributes to the regulation of CREB-mediated $\mathrm{Na}^{+} / \mathrm{K}^{+}$-ATPase expression in the vascular endothelium and is an important regulator of endothelial stiffness [83,84]. Besides promoting CREB activity, sAC also regulates several other transcription factors. For example, sAC supports hypercapnia-accelerated adipogenesis via the activation of pro-adipogenic transcription factors, such as CREB, CCAAT/enhancer binding protein $ß$ and proliferator-activated receptor $\gamma$ [85]. Similarly, sAC-PKA-dependent phosphorylation, and thus the activation of transcription factor 4 , is required for brain development [86].

\subsubsection{CFTR Regulation}

The Cystic Fibrosis Transmembrane Conductance Regulator (CFTR) is a chloride channel, primarily localized in the apical membrane of secretory epithelial cells. Mutations in the CFTR lead to the development of cystic fibrosis [87]. In cultured human airway epithelial cells, it has been found that sAC, activated by bicarbonate, modulates CFTR function in a PKA-dependent manner. The inhibition of sAC attenuated bicarbonate-stimulated CFTR activity [88]. Further studies have demonstrated that CFTR is involved in bicarbonate entry into granulosa cells, which further promotes the nuclear CAMP-PKA-CREB axis [89]. CFTR is involved in triggering sperm capacitation, as CFTR promotes bicarbonate secretion by the endometrium [90] which, in turn, activates sAC in sperm, increases cAMP production, and then activates PKA and the cyclic nucleotide gate cation channels [91,92]. Moreover, CFTR via the sAC-cAMP-PKA pathway has been shown to promote embryo development through the suppression of p53-dependent development arrest [93]. Taken together, the CFTR-sAC axis seems to play an important role in reproductive processes [94]. 


\subsection{6. $\mathrm{Na}^{+} / \mathrm{K}^{+}$-ATPas Endocytosis}

In alveolar epithelial cells, a high $\mathrm{CO}_{2}$ concentration promotes the sAC-cAMP axis, which in turn induces a PKA-dependent phosphorylation of $\alpha$-adducin, a component of the actin cytoskeleton, resulting in $\mathrm{Na}^{+} / \mathrm{K}^{+}$-ATPase endocytosis [95]. In the vascular endothelium, the role that the sAC-cAMP axis plays in $\mathrm{Na}^{+} / \mathrm{K}^{+}$-ATPase regulation has been demonstrated, as the inhibition of sAC (KH7 and interfering RNA) significantly decreases the mRNA and protein levels of $\mathrm{Na}^{+} / \mathrm{K}^{+}$-ATPase [84]. A recent study confirmed that the sAC-dependent regulation of $\mathrm{Na}^{+} / \mathrm{K}^{+}$-ATPase in the vascular endothelium plays an important role in endothelial stiffness [83].

\subsubsection{Endothelial Permeability}

The importance of the intracellular distribution of cAMP for endothelial barrier function has been demonstrated, because the stimulation of plasma membrane and cytosolic cAMP pools exerts the opposite effects $[96,97]$.

A recent study suggested that SAC has a protective effect on endothelial barrier function under inflammatory and hypoxic conditions [98]. In this study, the bicarbonate-mediated activation of sAC elevated cellular cAMP levels was followed by PKA and EPAC activation, which led to the inhibition of RhoA/Rock signaling and the translocation of VE-cadherin at cell-cell junctions. Moreover, sAC activation abrogated thrombin and hypoxia/reoxygenation-induced endothelial cells hyperpermeability. Pharmacological inhibition or knockdown of sAC worsened the thrombin-induced endothelial hyperpermeability suggesting that basal sAC activity is required for the maintenance of the endothelial barrier function under inflammatory conditions.

\subsection{Role of Mitochondrial sAC-Dependent cAMP Signaling}

\subsubsection{Extra-Mitochondrial sAC}

According to the current view on mitochondrial cAMP signaling, two main cores that contain distinct cAMP signaling pathways-the extra-mitochondrial sAC (outer mitochondrial membrane $(\mathrm{OMM})$ ) and intra-mitochondrial (the mitochondrial matrix)—can be distinguished [99]. The specificity of cAMP in OMM is mainly achieved through PKA tethering to OMM by several AKAPs, which allows multiple processes to be carried out, including mitochondrial protein import, autophagy, mitophagy, mitochondrial fission and fusion, and apoptosis [99]. Our recent study defined the role that sAC plays in regulating mitochondrial biogenesis and mitophagy [100].

It has been demonstrated that the cytosolic pool of cAMP generated by SAC is also involved in controlling mitochondrial apoptosis. Under stress conditions, the translocation of cytosolic SAC to the mitochondria leads to a selective activation of PKA, followed by phosphorylation and binding of the pro-apoptotic protein Bax to mitochondria and the release of cytochrome $\mathrm{c}$ in coronary endothelial cells, cardiomyocytes and aortic smooth muscle cells [15,101,102]. Furthermore, the overexpression of cytosolic SAC, but not intra-mitochondrial sAC, promotes the activation of the mitochondrial pathway of apoptosis under oxysterol treatment [102].

\subsubsection{Intra-Mitochondrial sAC}

An increasing amount of evidence suggests that intra-mitochondrial cAMP/PKA signaling is present in mammals $[8,45,103]$ and yeast [104]. Although transmembrane adenylyl cyclase was initially assumed to be a source of mitochondrial cAMP [105], a recent study [9] reconsidered this paradigm and demonstrated that cytosolic cAMP cannot permeate the inner mitochondrial membrane and a mitochondria-localized cAMP source, i.e., sAC, is required [99]. In a recent study [106] we confirmed the previously published findings [9] that activating plasmalemmal adenylyl cyclase with forskolin leads to a rapid elevation of cytosolic cAMP, but does not affect cAMP concentration in mitochondria. It is worth noting that we [106], as well as other authors [9,107,108], have all observed a rapid increase in intra-mitochondrial cAMP under sAC stimulation with bicarbonate. 
Bicarbonate and $\mathrm{Ca}^{2+}$ stimulation of mitochondrial sAC may couple the activity of the TCA cycle-the main source of $\mathrm{CO}_{2} /$ bicarbonate in the cell-and alterations in the intra-mitochondrial $\mathrm{Ca}^{2+}$ concentration to the OXPHOS activity [9]. Indeed, the seminal studies of Acin-Perez et al. demonstrated that cAMP produced in the mitochondrial matrix promotes cytochrome coxidase activity via a PKA-dependent phosphorylation of cytochrome c oxidase subunit IV [8,109]. Knockout of sAC in fibroblasts causes a decline in OXPHOS activity that is compensated with elevated OXPHOS expression, whereas restoring SAC expression in the mitochondrial matrix rescues OXPHOS activity [110]. Similar results (regulation of OXPHOS activity via cAMP-PKA axis) were obtained in yeast, where the inhibition of sAC caused a decline in respiration and OXPHOS activity [104]. Furthermore, in a study on human fibroblasts, the inhibition of sAC depressed complex I activity was rescued by adding a membrane-permeable cAMP analog [111].

The role of intra-mitochondrial SAC in the regulation of memory processing was recently demonstrated [45]. The authors suggested that the activation of mitochondrial localized type- 1 cannabinoid receptors $\left(\mathrm{mtCB}_{1}\right)$ decreases mitochondrial cAMP, complex I activity, mitochondrial respiration and cellular ATP content in hippocampal cell culture. In their study bicarbonate stimulation fully reversed the effect of $\mathrm{mtCB}_{1}$-receptor activation and eliminated the cannabinoid-induced reduction in respiration. The study also confirmed that the modulation of brain mitochondrial respiration occurs through the PKA-dependent phosphorylation of complex I subunit NDUFS2 [45].

In addition to the post-translational regulation of OXPHOS activity via PKA-dependent phosphorylation, [8] it has also been suggested that sAC has an effect on the turnover of OXPHOS proteins. Indeed, intra-mitochondrial cAMP prevents the digestion of nuclear-encoded subunits of complex I by mitochondrial proteases and supports its NADH-ubiquinone oxidoreductase activity [111].

Aside from the above-mentioned studies, several other reports have demonstrated the presence of functional PKA in the mitochondrial matrix [112,113]. In a notable study that applied a PKA-sensing system with a robust dynamic range, Agnes et al. [113] characterized the compartmentalized location of PKA activity as being in bovine heart mitochondria. The experimentally determined PKA activity ratio—79:8:13 in mitochondrial matrix/intermembrane space/outer membrane respectively—provided evidence that the major PKA activity is located in the mitochondrial matrix. In agreement with that study, Sardanelli et al. [112], applying densitometric immunoblot analysis and activity assays, concluded that the majority ( $90 \%)$ of mitochondrial PKA is localized in the inner mitochondrial compartment. Nevertheless, this issue of PKA localization is still a matter of debate [114]. Indeed, applying FRET-based analysis of PKA activity Lefkimmiatis et al. found no evidence of PKA activity in the mitochondrial matrix [115]. In addition, it was demonstrated that calcium-induced cardiac mitochondrial respiration is PKA independent [116]. This obvious discrepancy may be due to differences in the methods used in the analysis of PKA activity or cell models (reviewed in Valsecchi et al. [114]). In fact, the absence of PKA activity in Lefkimmiatis's study may be due to the use of predominantly glycolytic cell lines, i.e., HeLa and HEK cells. In addition, in many studies PKA activity was examined through treatment with H89, which is an unspecific PKA inhibitor and may lead to numerous side effects.

Though PKA has long been considered the most active kinase in the matrix and the main effector of intra-mitochondrial cAMP [12], another cAMP downstream target involved in the regulation of mitochondrial function-EPAC—has also been described [117]. The mitochondrial sAC-cAMP-EPAC pathway regulates coupling efficiency and the structural organization of $\mathrm{F}_{0} \mathrm{~F}_{1}$ ATP synthase in mammalian mitochondria [118]. In a recent study, Wang et al. [107] demonstrated a down-regulation of sAC in an animal model of heart failure, which was accompanied by a reduced resistance to $\mathrm{Ca}^{2+}$ overload in cardiac mitochondria. The authors underlined the inhibitory effect of the $\mathrm{sAC} / \mathrm{cAMP} /$ Epac1 axis on the $\mathrm{Ca}^{2+}$ overload-induced opening of mitochondrial permeability pore transition [107]. In contrast, a study by Fazal et al. [119] postulated that activation of the mitochondrial 
sAC-cAMP-EPAC axis stimulates the mitochondrial $\mathrm{Ca}^{2+}$ entry, the opening of mitochondrial permeability pore transition and cell death.

\subsubsection{Intra-Mitochondrial PDE2}

In addition to the SAC, PDEs also contribute to the intra-mitochondrial cAMP level. PDE2A has been found to be a predominant intra-mitochondrial isoform [103]. This PDE is activated by cGMP that enables a negative cGMP-cAMP cross-talk $[103,120]$. A study performed with mitochondria isolated from mouse brains suggested that PDE2A, and the PDE2A2 isoform in particular, is localized in the mitochondrial matrix - due to the mitochondrial targeted sequence at $\mathrm{N}$ terminus of PDE2A2-where it regulates the activity of the mitochondrial respiratory chain [103]. Applying the super-resolution stimulated emission depletion microscopy in neonatal rat ventricular myocytes, Monterisi et al. revealed the localization of PDE2A outside of the mitochondrial matrix, particularly at the outer or inner mitochondrial membrane, where it regulates mitochondrial morphology, mitochondrial membrane potential and cell death via sAC-independent mechanisms [121]. Further investigation is required to clarify the localization and activity of PDE2 in mitochondria.

Since the PDE2 is activated by cGMP, it is tempting to speculate that an activation of NO signaling may lead to the activation of mitochondrial PDE2. In fact, our new report demonstrated a decline in mitochondrial cAMP concentration after NO signaling activation, either by NO donor or estradiol, in a PDE2- and sGC-dependent manner [106]. It is worth nothing that the localization of sGC in mitochondria was confirmed by western blot analysis. The reduction of mitochondrial cAMP level was accompanied by a decline in mitochondrial COX activity in a PDE2-dependent manner [106]. These data are in agreement with a previous report that demonstrated that the inhibition of PDE2A with BAY60-7550 increases oxygen consumption and ATP production in isolated mitochondria [103].

To prove whether the beneficial effect of PDE2 inhibition may be translated to cardiac pathology, adult rat cardiomyocytes were challenged metabolically with cyanide followed by a recovery phase. Inhibition of PDE2A with BAY60-7550 significantly improved cell viability [122]. In alignment with these results, a recent report suggested that PDE2 inhibition has a protective effect in a brain ischemia/reperfusion model, although it was delayed rather than acute effects of reperfusion that were analyzed [123]. Similarly, an inhibition of matrix localized PDE2A with BAY60-7550 reduced the uncoupled respiration rate and increased cytochrome c oxidase activity in septic mice [124].

\subsection{Importance of $s A C$ in the Cardiovascular System}

The role of cAMP in the regulation of numerous physiological and pathological processes in the heart is well known [125-127]. Nevertheless, knowledge about the role of sAC in the cardiovascular system is limited. A seminal study by Sayner et al. [97] showed sAC's regulation of endothelial barrier function. We have also demonstrated that SAC plays a role in cardiovascular apoptosis $[15,101]$. The importance of sAC in cardiac pathology, like heart failure, has recently been suggested by Wang et al. [107]. The authors revealed a dramatic downregulation of sAC in mitochondrial fraction isolated from rat hearts at the late phase of cardiomyopathy and linked it to the reduced $\mathrm{Ca}^{2+}$ resistance of mitochondria. Our recent study presented further evidence of the importance of sAC in cardiac hypotrophy induced by isoprenaline (isolated cardiomyocytes) or pressure overload (sAC-knockout mice) [72].

\section{Conclusions}

cAMP signaling plays a fundamental role in controlling numerous cellular functions. The system is complex and has a well-organized spatiotemporal structure. Different mechanisms are involved in the compartmentalized structure of cAMP within the cell, including phosphodiesterases, tmACand SAC-dependent cAMP sources. The discovery of sAC as an alternative, intracellular source of cAMP significantly expands our knowledge of the spatial compartmentalization of cAMP signaling. The multifunctional role of SAC in the regulation of mitochondrial function and transcriptional activity 
in the cells, together with other functions described in this review, shows how important this cyclase is for cellular and organismal homeostasis and health. In this light, an in-depth understanding of sAC biology may contribute significantly to the prevention, prediction and treatment of several pathologies. The appearance of recent data describing the role of sAC in cardiovascular physiology [9] and pathology $[11,15,72,102,107,119,124]$ is not surprising, especially considering the fundamental role that cAMP signaling plays in the regulation of heart function.

Author Contributions: S.P. and Y.L. wrote the manuscript.

Acknowledgments: This study was supported by DZHK (German Centre for Cardiovascular Research) partner site Berlin (Project DZHK TP BER 3.2 HF).

Conflicts of Interest: The authors declare no conflict of interest.

\section{Abbreviations}

$\begin{array}{ll}\text { CAMP } & 3^{\prime}-5^{\prime} \text {-cyclic adenosine monophosphate } \\ \text { SAC } & \text { soluble adenylyl cyclase } \\ \text { tmAC } & \text { transmembrane adenylyl cyclase } \\ \text { PDEs } & \text { phosphodiesterases } \\ \text { PKA } & \text { protein kinase A } \\ \text { EPAC } & \text { exchange protein directly activated by cAMP } \\ \text { CREB } & \text { cAMP-response element binding protein } \\ \text { CE } & \text { Catechol estrogens } \\ \text { GC } & \text { guanylyl cyclase } \\ \text { AKAP } & \text { A-kinase anchoring proteins } \\ \text { CFTR } & \text { cystic fibrosis transmembrane conductance regulator } \\ \text { V-ATPase } & \text { vacuolar H }{ }^{+} \text {-ATPase } \\ \text { IMS } & \text { intra-mitochondrial space } \\ \text { OMM } & \text { outer mitochondrial membrane } \\ \text { IMM } & \text { inner mitochondrial membrane } \\ \text { NTPase } & \text { nucleoside-triphosphatase } \\ \text { OXPHOS } & \text { oxidative phosphorylation }\end{array}$

\section{References}

1. Wu, Z.; Huang, X.; Feng, Y.; Handschin, C.; Feng, Y.; Gullicksen, P.S.; Bare, O.; Labow, M.; Spiegelman, B.; Stevenson, S.C. Transducer of regulated CREB-binding proteins (TORCs) induce PGC-1 $\alpha$ transcription and mitochondrial biogenesis in muscle cells. Proc. Natl. Acad. Sci. USA 2006, 103, 14379-14384. [CrossRef] [PubMed]

2. Chowanadisai, W.; Bauerly, K.A.; Tchaparian, E.; Wong, A.; Cortopassi, G.A.; Rucker, R.B. Pyrroloquinoline quinone stimulates mitochondrial biogenesis through cAMP response element-binding protein phosphorylation and increased PGC-1 $\alpha$ expression. J. Biol. Chem. 2010, 285, 142-152. [CrossRef] [PubMed]

3. Catterall, W.A. Regulation of cardiac calcium channels in the fight-or-flight response. Curr. Mol. Pharmacol. 2015, 8, 12-21. [CrossRef] [PubMed]

4. Kashina, A.S.; Semenova, I.V.; Ivanov, P.A.; Potekhina, E.S.; Zaliapin, I.; Rodionov, V.I. Protein kinase A, which regulates intracellular transport, forms complexes with molecular motors on organelles. Curr. Biol. 2004, 14, 1877-1881. [CrossRef] [PubMed]

5. Burdyga, A.; Conant, A.; Haynes, L.; Zhang, J.; Jalink, K.; Sutton, R.; Neoptolemos, J.; Costello, E.; Tepikin, A. cAMP inhibits migration, ruffling and paxillin accumulation in focal adhesions of pancreatic ductal adenocarcinoma cells: Effects of PKA and EPAC. Biochim. Biophys. Acta 2013, 1833, $2664-2672$. [CrossRef] [PubMed]

6. Zimmerman, N.P.; Roy, I.; Hauser, A.D.; Wilson, J.M.; Williams, C.L.; Dwinell, M.B. Cyclic AMP regulates the migration and invasion potential of human pancreatic cancer cells. Mol. Carcinog. 2015, 54, $203-215$. [CrossRef] [PubMed] 
7. Acin-Perez, R.; Salazar, E.; Brosel, S.; Yang, H.; Schon, E.A.; Manfredi, G. Modulation of mitochondrial protein phosphorylation by soluble adenylyl cyclase ameliorates cytochrome oxidase defects. EMBO Mol. Med. 2009, 1, 392-406. [CrossRef] [PubMed]

8. Acin-Perez, R.; Salazar, E.; Kamenetsky, M.; Buck, J.; Levin, L.R.; Manfredi, G. Cyclic AMP produced inside mitochondria regulates oxidative phosphorylation. Cell Metab. 2009, 9, 265-276. [CrossRef] [PubMed]

9. Di Benedetto, G.; Scalzotto, E.; Mongillo, M.; Pozzan, T. Mitochondrial $\mathrm{Ca}^{2+}$ uptake induces cyclic AMP generation in the matrix and modulates organelle ATP levels. Cell Metab. 2013, 17, 965-975. [CrossRef] [PubMed]

10. Valsecchi, F.; Ramos-Espiritu, L.S.; Buck, J.; Levin, L.R.; Manfredi, G. cAMP and mitochondria. Physiology 2013, 28, 199-209. [CrossRef] [PubMed]

11. Signorile, A.; Santeramo, A.; Tamma, G.; Pellegrino, T.; D’Oria, S.; Lattanzio, P.; De Rasmo, D. Mitochondrial cAMP prevents apoptosis modulating Sirt3 protein level and OPA1 processing in cardiac myoblast cells. Biochim. Biophys. Acta 2017, 1864, 355-366. [CrossRef] [PubMed]

12. Zhang, F.; Zhang, L.; Qi, Y.; Xu, H. Mitochondrial cAMP signaling. Cell. Mol. Life Sci. 2016, 73, 4577-4590. [CrossRef] [PubMed]

13. Bacallao, K.; Monje, P.V. Opposing roles of PKA and EPAC in the cAMP-dependent regulation of schwann cell proliferation and differentiation [corrected]. PLoS ONE 2013, 8, e82354. [CrossRef] [PubMed]

14. Stork, P.J.; Schmitt, J.M. Crosstalk between cAMP and MAP kinase signaling in the regulation of cell proliferation. Trends Cell Biol. 2002, 12, 258-266. [CrossRef]

15. Appukuttan, A.; Kasseckert, S.A.; Micoogullari, M.; Flacke, J.P.; Kumar, S.; Woste, A.; Abdallah, Y.; Pott, L.; Reusch, H.P.; Ladilov, Y. Type 10 adenylyl cyclase mediates mitochondrial bax translocation and apoptosis of adult rat cardiomyocytes under simulated ischaemia/reperfusion. Cardiovasc. Res. 2012, 93, 340-349. [CrossRef] [PubMed]

16. Ladilov, Y.; Appukuttan, A. Role of soluble adenylyl cyclase in cell death and growth. Biochim. Biophys. Acta 2014, 1842, 2646-2655. [CrossRef] [PubMed]

17. Ohmori, M.; Okamoto, S. Photoresponsive cAMP signal transduction in cyanobacteria. Photochem. Photobiol. Sci. 2004, 3, 503-511. [CrossRef] [PubMed]

18. Knapp, G.S.; McDonough, K.A. Cyclic amp signaling in mycobacteria. In Molecular Genetics of Mycobacteria, 2nd ed.; American Society of Microbiology: Washington, DC, USA, 2014; pp. 281-295.

19. Kamenetsky, M.; Middelhaufe, S.; Bank, E.M.; Levin, L.R.; Buck, J.; Steegborn, C. Molecular details of cAMP generation in mammalian cells: A tale of two systems. J. Mol. Biol. 2006, 362, 623-639. [CrossRef] [PubMed]

20. Federman, A.D.; Conklin, B.R.; Schrader, K.A.; Reed, R.R.; Bourne, H.R. Hormonal stimulation of adenylyl cyclase through Gi-protein $\beta \gamma$ subunits. Nature 1992, 356, 159-161. [CrossRef] [PubMed]

21. Dessauer, C.W.; Watts, V.J.; Ostrom, R.S.; Conti, M.; Dove, S.; Seifert, R. International union of basic and clinical pharmacology. Ci. Structures and small molecule modulators of mammalian adenylyl cyclases. Pharmacol. Rev. 2017, 69, 93-139. [CrossRef] [PubMed]

22. Baldwin, T.A.; Dessauer, C.W. Function of adenylyl cyclase in heart: The AKAP connection. J. Cardiovasc. Dev. Dis. 2018, 5, 2. [CrossRef] [PubMed]

23. Ostrom, R.S.; Naugle, J.E.; Hase, M.; Gregorian, C.; Swaney, J.S.; Insel, P.A.; Brunton, L.L.; Meszaros, J.G. Angiotensin ii enhances adenylyl cyclase signaling via $\mathrm{Ca}^{2+} /$ calmodulin. Gq-Gs cross-talk regulates collagen production in cardiac fibroblasts. J. Biol. Chem. 2003, 278, 24461-24468. [CrossRef] [PubMed]

24. Chen, Y.; Cann, M.J.; Litvin, T.N.; Iourgenko, V.; Sinclair, M.L.; Levin, L.R.; Buck, J. Soluble adenylyl cyclase as an evolutionarily conserved bicarbonate sensor. Science 2000, 289, 625-628. [CrossRef] [PubMed]

25. Zippin, J.H.; Chen, Y.; Nahirney, P.; Kamenetsky, M.; Wuttke, M.S.; Fischman, D.A.; Levin, L.R.; Buck, J. Compartmentalization of bicarbonate-sensitive adenylyl cyclase in distinct signaling microdomains. FASEB J. 2003, 17, 82-84. [CrossRef] [PubMed]

26. Richards, M.; Lomas, O.; Jalink, K.; Ford, K.L.; Vaughan-Jones, R.D.; Lefkimmiatis, K.; Swietach, P. Intracellular tortuosity underlies slow cAMP diffusion in adult ventricular myocytes. Cardiovasc. Res. 2016, 110, 395-407. [CrossRef] [PubMed]

27. Mika, D.; Leroy, J.; Vandecasteele, G.; Fischmeister, R. Pdes create local domains of cAMP signaling. J. Mol. Cell. Cardiol. 2012, 52, 323-329. [CrossRef] [PubMed]

28. Agarwal, S.R.; Clancy, C.E.; Harvey, R.D. Mechanisms restricting diffusion of intracellular cAMP. Sci. Rep. 2016, 6, 19577. [CrossRef] [PubMed] 
29. Fischmeister, R.; Castro, L.R.; Abi-Gerges, A.; Rochais, F.; Jurevicius, J.; Leroy, J.; Vandecasteele, G. Compartmentation of cyclic nucleotide signaling in the heart: The role of cyclic nucleotide phosphodiesterases. Circ. Res. 2006, 99, 816-828. [CrossRef] [PubMed]

30. Godbole, A.; Lyga, S.; Lohse, M.J.; Calebiro, D. Internalized tsh receptors en route to the tgn induce local Gs-protein signaling and gene transcription. Nat. Commun. 2017, 8, 443. [CrossRef] [PubMed]

31. Calebiro, D.; Maiellaro, I. CAMP signaling microdomains and their observation by optical methods. Front. Cell. Neurosci. 2014, 8, 350. [CrossRef] [PubMed]

32. Musheshe, N.; Schmidt, M.; Zaccolo, M. cAMP: From long-range second messenger to nanodomain signalling. Trends Pharmacol. Sci. 2017, 39, 209-222. [CrossRef] [PubMed]

33. Lefkimmiatis, K.; Zaccolo, M. cAMP signaling in subcellular compartments. Pharmacol. Ther. 2014, 143, 295-304. [CrossRef] [PubMed]

34. Kobayashi, M.; Buck, J.; Levin, L.R. Conservation of functional domain structure in bicarbonate-regulated "soluble" adenylyl cyclases in bacteria and eukaryotes. Dev. Genes Evol. 2004, 214, 503-509. [CrossRef] [PubMed]

35. Kleinboelting, S.; Diaz, A.; Moniot, S.; van den Heuvel, J.; Weyand, M.; Levin, L.R.; Buck, J.; Steegborn, C. Crystal structures of human soluble adenylyl cyclase reveal mechanisms of catalysis and of its activation through bicarbonate. Proc. Natl. Acad. Sci. USA 2014, 111, 3727-3732. [CrossRef] [PubMed]

36. Chaloupka, J.A.; Bullock, S.A.; Iourgenko, V.; Levin, L.R.; Buck, J. Autoinhibitory regulation of soluble adenylyl cyclase. Mol. Reprod. Dev. 2006, 73, 361-368. [CrossRef] [PubMed]

37. Leipe, D.D.; Koonin, E.V.; Aravind, L. Stand, a class of p-loop ntpases including animal and plant regulators of programmed cell death: Multiple, complex domain architectures, unusual phyletic patterns, and evolution by horizontal gene transfer. J. Mol. Biol. 2004, 343, 1-28. [CrossRef] [PubMed]

38. Middelhaufe, S.; Leipelt, M.; Levin, L.R.; Buck, J.; Steegborn, C. Identification of a haem domain in human soluble adenylate cyclase. Biosci. Rep. 2012, 32, 491-499. [CrossRef] [PubMed]

39. Farrell, J.; Ramos, L.; Tresguerres, M.; Kamenetsky, M.; Levin, L.R.; Buck, J. Somatic 'soluble' adenylyl cyclase

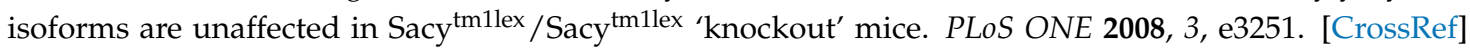
[PubMed]

40. Reed, B.Y.; Gitomer, W.L.; Heller, H.J.; Hsu, M.C.; Lemke, M.; Padalino, P.; Pak, C.Y. Identification and characterization of a gene with base substitutions associated with the absorptive hypercalciuria phenotype and low spinal bone density. J. Clin. Endocrinol. Metab. 2002, 87, 1476-1485. [CrossRef] [PubMed]

41. Chen, X.; Baumlin, N.; Buck, J.; Levin, L.R.; Fregien, N.; Salathe, M. A soluble adenylyl cyclase form targets to axonemes and rescues beat regulation in soluble adenylyl cyclase knockout mice. Am. J. Respir. Cell Mol. Biol. 2014, 51, 750-760. [CrossRef] [PubMed]

42. Buck, J.; Sinclair, M.L.; Schapal, L.; Cann, M.J.; Levin, L.R. Cytosolic adenylyl cyclase defines a unique signaling molecule in mammals. Proc. Natl. Acad. Sci. USA 1999, 96, 79-84. [CrossRef] [PubMed]

43. Geng, W.; Wang, Z.; Zhang, J.; Reed, B.Y.; Pak, C.Y.; Moe, O.W. Cloning and characterization of the human soluble adenylyl cyclase. Am. J. Physiol. Cell Physiol. 2005, 288, C1305-C1316. [CrossRef] [PubMed]

44. Steegborn, C. Structure, mechanism, and regulation of soluble adenylyl cyclases-Similarities and differences to transmembrane adenylyl cyclases. Biochim. Biophys. Acta 2014, 1842, 2535-2547. [CrossRef] [PubMed]

45. Hebert-Chatelain, E.; Desprez, T.; Serrat, R.; Bellocchio, L.; Soria-Gomez, E.; Busquets-Garcia, A.; Pagano Zottola, A.C.; Delamarre, A.; Cannich, A.; Vincent, P.; et al. A cannabinoid link between mitochondria and memory. Nature 2016, 539, 555-559. [CrossRef] [PubMed]

46. Ramos-Espiritu, L.; Kleinboelting, S.; Navarrete, F.A.; Alvau, A.; Visconti, P.E.; Valsecchi, F.; Starkov, A.; Manfredi, G.; Buck, H.; Adura, C.; et al. Discovery of LRE1 as a specific and allosteric inhibitor of soluble adenylyl cyclase. Nat. Chem. Biol. 2016, 12, 838-844. [CrossRef] [PubMed]

47. Tresguerres, M.; Levin, L.R.; Buck, J. Intracellular cAMP signaling by soluble adenylyl cyclase. Kidney Int. 2011, 79, 1277-1288. [CrossRef] [PubMed]

48. Zippin, J.H.; Chen, Y.; Straub, S.G.; Hess, K.C.; Diaz, A.; Lee, D.; Tso, P.; Holz, G.G.; Sharp, G.W.; Levin, L.R.; et al. $\mathrm{CO}_{2} / \mathrm{HCO}_{3}{ }^{-}$- and calcium-regulated soluble adenylyl cyclase as a physiological ATP sensor. J. Biol. Chem. 2013, 288, 33283-33291. [CrossRef] [PubMed]

49. Litvin, T.N.; Kamenetsky, M.; Zarifyan, A.; Buck, J.; Levin, L.R. Kinetic properties of "soluble" adenylyl cyclase. Synergism between calcium and bicarbonate. J. Biol. Chem. 2003, 278, 15922-15926. [CrossRef] [PubMed] 
50. Magro, C.M.; Yang, S.E.; Zippin, J.H.; Zembowicz, A. Expression of soluble adenylyl cyclase in lentigo maligna: Use of immunohistochemistry with anti-soluble adenylyl cyclase antibody (R21) in diagnosis of lentigo maligna and assessment of margins. Arch. Pathol. Lab. Med. 2012, 136, 1558-1564. [CrossRef] [PubMed]

51. Magro, C.M.; Crowson, A.N.; Desman, G.; Zippin, J.H. Soluble adenylyl cyclase antibody profile as a diagnostic adjunct in the assessment of pigmented lesions. Arch. Dermatol. 2012, 148, 335-344. [CrossRef] [PubMed]

52. Ramos, L.S.; Zippin, J.H.; Kamenetsky, M.; Buck, J.; Levin, L.R. Glucose and GLP-1 stimulate cAMP production via distinct adenylyl cyclases in INS-1E insulinoma cells. J. Gen. Physiol. 2008, 132, 329-338. [CrossRef] [PubMed]

53. Flacke, J.P.; Flacke, H.; Appukuttan, A.; Palisaar, R.J.; Noldus, J.; Robinson, B.D.; Reusch, H.P.; Zippin, J.H.; Ladilov, Y. Type 10 soluble adenylyl cyclase is overexpressed in prostate carcinoma and controls proliferation of prostate cancer cells. J. Biol. Chem. 2013, 288, 3126-3135. [CrossRef] [PubMed]

54. Pierre, S.; Eschenhagen, T.; Geisslinger, G.; Scholich, K. Capturing adenylyl cyclases as potential drug targets. Nat. Rev. Drug Discov. 2009, 8, 321-335. [CrossRef] [PubMed]

55. Lee, Y.S.; Tresguerres, M.; Hess, K.; Marmorstein, L.Y.; Levin, L.R.; Buck, J.; Marmorstein, A.D. Regulation of anterior chamber drainage by bicarbonate-sensitive soluble adenylyl cyclase in the ciliary body. J. Biol. Chem. 2011, 286, 41353-41358. [CrossRef] [PubMed]

56. Bitterman, J.L.; Ramos-Espiritu, L.; Diaz, A.; Levin, L.R.; Buck, J. Pharmacological distinction between soluble and transmembrane adenylyl cyclases. J. Pharmacol. Exp. Ther. 2013, 347, 589-598. [CrossRef] [PubMed]

57. Steegborn, C.; Litvin, T.N.; Hess, K.C.; Capper, A.B.; Taussig, R.; Buck, J.; Levin, L.R.; Wu, H. A novel mechanism for adenylyl cyclase inhibition from the crystal structure of its complex with catechol estrogen. J. Biol. Chem. 2005, 280, 31754-31759. [CrossRef] [PubMed]

58. Hess, K.C.; Jones, B.H.; Marquez, B.; Chen, Y.; Ord, T.S.; Kamenetsky, M.; Miyamoto, C.; Zippin, J.H.; Kopf, G.S.; Suarez, S.S.; et al. The "soluble" adenylyl cyclase in sperm mediates multiple signaling events required for fertilization. Dev. Cell 2005, 9, 249-259. [CrossRef] [PubMed]

59. Kaupp, U.B.; Seifert, R. Cyclic nucleotide-gated ion channels. Physiol. Rev. 2002, 82, 769-824. [CrossRef] [PubMed]

60. Froese, A.; Breher, S.S.; Waldeyer, C.; Schindler, R.F.; Nikolaev, V.O.; Rinne, S.; Wischmeyer, E.; Schlueter, J.; Becher, J.; Simrick, S.; et al. Popeye domain containing proteins are essential for stress-mediated modulation of cardiac pacemaking in mice. J. Clin. Investig. 2012, 122, 1119-1130. [CrossRef] [PubMed]

61. Simrick, S.; Schindler, R.F.; Poon, K.L.; Brand, T. Popeye domain-containing proteins and stress-mediated modulation of cardiac pacemaking. Trends Cardiovasc. Med. 2013, 23, 257-263. [CrossRef] [PubMed]

62. Schmidt, M.; Dekker, F.J.; Maarsingh, H. Exchange protein directly activated by cAMP (EPAC): A multidomain cAMP mediator in the regulation of diverse biological functions. Pharmacol. Rev. 2013, 65, 670-709. [CrossRef] [PubMed]

63. Lomas, O.; Zaccolo, M. Phosphodiesterases maintain signaling fidelity via compartmentalization of cyclic nucleotides. Physiology 2014, 29, 141-149. [CrossRef] [PubMed]

64. Corredor, R.G.; Trakhtenberg, E.F.; Pita-Thomas, W.; Jin, X.; Hu, Y.; Goldberg, J.L. Soluble adenylyl cyclase activity is necessary for retinal ganglion cell survival and axon growth. J. Neurosci. 2012, 32, 7734-7744. [CrossRef] [PubMed]

65. Han, H.; Stessin, A.; Roberts, J.; Hess, K.; Gautam, N.; Kamenetsky, M.; Lou, O.; Hyde, E.; Nathan, N.; Muller, W.A.; et al. Calcium-sensing soluble adenylyl cyclase mediates tnf signal transduction in human neutrophils. J. Exp. Med. 2005, 202, 353-361. [CrossRef] [PubMed]

66. Stowe, D.F.; Gadicherla, A.K.; Zhou, Y.; Aldakkak, M.; Cheng, Q.; Kwok, W.M.; Jiang, M.T.; Heisner, J.S.; Yang, M.; Camara, A.K. Protection against cardiac injury by small $\mathrm{Ca}^{2+}$-sensitive $\mathrm{K}^{+}$channels identified in guinea pig cardiac inner mitochondrial membrane. Biochim. Biophys. Acta 2013, 1828, 427-442. [CrossRef] [PubMed]

67. Monterisi, S.; Zaccolo, M. Components of the mitochondrial cAMP signalosome. Biochem. Soc. Trans. 2017, 45, 269-274. [CrossRef] [PubMed] 
68. Zippin, J.H.; Farrell, J.; Huron, D.; Kamenetsky, M.; Hess, K.C.; Fischman, D.A.; Levin, L.R.; Buck, J. Bicarbonate-responsive "soluble" adenylyl cyclase defines a nuclear cAMP microdomain. J. Cell Biol. 2004, 164, 527-534. [CrossRef] [PubMed]

69. Stessin, A.M.; Zippin, J.H.; Kamenetsky, M.; Hess, K.C.; Buck, J.; Levin, L.R. Soluble adenylyl cyclase mediates nerve growth factor-induced activation of Rap1. J. Biol. Chem. 2006, 281, 17253-17258. [CrossRef] [PubMed]

70. Onodera, Y.; Nam, J.M.; Bissell, M.J. Increased sugar uptake promotes oncogenesis via EPAC/Rap1 and o-glcnac pathways. J. Clin. Investig. 2014, 124, 367-384. [CrossRef] [PubMed]

71. Wu, K.Y.; Zippin, J.H.; Huron, D.R.; Kamenetsky, M.; Hengst, U.; Buck, J.; Levin, L.R.; Jaffrey, S.R. Soluble adenylyl cyclase is required for netrin-1 signaling in nerve growth cones. Nat. Neurosci. 2006, 9, 1257-1264. [CrossRef] [PubMed]

72. Schirmer, I.; Bualeong, T.; Budde, H.; Cimiotti, D.; Appukuttan, A.; Klein, N.; Steinwascher, P.; Reusch, P.; Mugge, A.; Meyer, R.; et al. Soluble adenylyl cyclase: A novel player in cardiac hypertrophy induced by isoprenaline or pressure overload. PLoS ONE 2018, 13, e0192322. [CrossRef] [PubMed]

73. Buffone, M.G.; Wertheimer, E.V.; Visconti, P.E.; Krapf, D. Central role of soluble adenylyl cyclase and cAMP in sperm physiology. Biochim. Biophys. Acta 2014, 1842, 2610-2620. [CrossRef] [PubMed]

74. Esposito, G.; Jaiswal, B.S.; Xie, F.; Krajnc-Franken, M.A.; Robben, T.J.; Strik, A.M.; Kuil, C.; Philipsen, R.L.; van Duin, M.; Conti, M.; et al. Mice deficient for soluble adenylyl cyclase are infertile because of a severe sperm-motility defect. Proc. Natl. Acad. Sci. USA 2004, 101, 2993-2998. [CrossRef] [PubMed]

75. Watson, R.L.; Buck, J.; Levin, L.R.; Winger, R.C.; Wang, J.; Arase, H.; Muller, W.A. Endothelial cd99 signals through soluble adenylyl cyclase and PKA to regulate leukocyte transendothelial migration. J. Exp. Med. 2015, 212, 1021-1041. [CrossRef] [PubMed]

76. Chang, J.C.; Oude-Elferink, R.P. Role of the bicarbonate-responsive soluble adenylyl cyclase in pH sensing and metabolic regulation. Front. Physiol. 2014, 5, 42. [CrossRef] [PubMed]

77. Brown, D.; Bouley, R.; Paunescu, T.G.; Breton, S.; Lu, H.A. New insights into the dynamic regulation of water and acid-base balance by renal epithelial cells. Am. J. Physiol. Cell Physiol. 2012, 302, C1421-C1433. [CrossRef] [PubMed]

78. Pastor-Soler, N.M.; Hallows, K.R.; Smolak, C.; Gong, F.; Brown, D.; Breton, S. Alkaline ph- and cAMP-induced $\mathrm{v}$-ATPase membrane accumulation is mediated by protein kinase a in epididymal clear cells. Am. J. Physiol. Cell Physiol. 2008, 294, C488-C494. [CrossRef] [PubMed]

79. Gong, F.; Alzamora, R.; Smolak, C.; Li, H.; Naveed, S.; Neumann, D.; Hallows, K.R.; Pastor-Soler, N.M. Vacuolar h+-atpase apical accumulation in kidney intercalated cells is regulated by PKA and AMP-activated protein kinase. Am. J. Physiol.-Renal Physiol. 2010, 298, F1162-F1169. [CrossRef] [PubMed]

80. Breton, S.; Brown, D. Regulation of luminal acidification by the v-atpase. Physiology 2013, 28, 318-329. [CrossRef] [PubMed]

81. Rahman, N.; Ramos-Espiritu, L.; Milner, T.A.; Buck, J.; Levin, L.R. Soluble adenylyl cyclase is essential for proper lysosomal acidification. J. Gen. Physiol. 2016, 148, 325-339. [CrossRef] [PubMed]

82. Inda, C.; Bonfiglio, J.J.; Dos Santos Claro, P.A.; Senin, S.A.; Armando, N.G.; Deussing, J.M.; Silberstein, S. cAMP-dependent cell differentiation triggered by activated crhr1 in hippocampal neuronal cells. Sci. Rep. 2017, 7, 1944. [CrossRef] [PubMed]

83. Mewes, M.; Nedele, J.; Schelleckes, K.; Bondareva, O.; Lenders, M.; Kusche-Vihrog, K.; Schnittler, H.J.; Brand, S.M.; Schmitz, B.; Brand, E. Salt-induced $\mathrm{Na}^{+} / \mathrm{K}^{+}$-atpase-alpha/beta expression involves soluble adenylyl cyclase in endothelial cells. Pflugers Arch. Eur. J. Physiol. 2017, 469, 1401-1412. [CrossRef] [PubMed]

84. Schmitz, B.; Nedele, J.; Guske, K.; Maase, M.; Lenders, M.; Schelleckes, M.; Kusche-Vihrog, K.; Brand, S.M.; Brand, E. Soluble adenylyl cyclase in vascular endothelium: Gene expression control of epithelial sodium channel-alpha, $\mathrm{Na}^{+} / \mathrm{K}^{+}$-ATPase- $\alpha / \beta$, and mineralocorticoid receptor. Hypertension 2014, 63, 753-761. [CrossRef] [PubMed]

85. Kikuchi, R.; Tsuji, T.; Watanabe, O.; Yamaguchi, K.; Furukawa, K.; Nakamura, H.; Aoshiba, K. Hypercapnia accelerates adipogenesis: A novel role of high $\mathrm{CO}_{2}$ in exacerbating obesity. Am. J. Respir. Cell Mol. Biol. 2017, 57, 570-580. [CrossRef] [PubMed]

86. Sepp, M.; Vihma, H.; Nurm, K.; Urb, M.; Page, S.C.; Roots, K.; Hark, A.; Maher, B.J.; Pruunsild, P.; Timmusk, T. The intellectual disability and schizophrenia associated transcription factor tcf 4 is regulated by neuronal activity and protein kinase a. J. Neurosci. 2017, 37, 10516-10527. [CrossRef] [PubMed] 
87. Lim, S.H.; Legere, E.A.; Snider, J.; Stagljar, I. Recent progress in cftr interactome mapping and its importance for cystic fibrosis. Front. Pharmacol. 2017, 8, 997. [CrossRef] [PubMed]

88. Wang, Y.; Lam, C.S.; Wu, F.; Wang, W.; Duan, Y.; Huang, P. Regulation of cftr channels by $\mathrm{HCO}_{3}$-Sensitive soluble adenylyl cyclase in human airway epithelial cells. Am. J. Physiol. Cell Physiol. 2005, 289, C1145-C1151. [CrossRef] [PubMed]

89. Chen, H.; Guo, J.H.; Lu, Y.C.; Ding, G.L.; Yu, M.K.; Tsang, L.L.; Fok, K.L.; Liu, X.M.; Zhang, X.H.; Chung, Y.W.; et al. Impaired cftr-dependent amplification of fsh-stimulated estrogen production in cystic fibrosis and pcos. J. Clin. Endocrinol. Metab. 2012, 97, 923-932. [CrossRef] [PubMed]

90. Wang, X.F.; Zhou, C.X.; Shi, Q.X.; Yuan, Y.Y.; Yu, M.K.; Ajonuma, L.C.; Ho, L.S.; Lo, P.S.; Tsang, L.L.; Liu, Y.; et al. Involvement of cftr in uterine bicarbonate secretion and the fertilizing capacity of sperm. Nat. Cell Biol. 2003, 5, 902-906. [CrossRef] [PubMed]

91. Xu, W.M.; Shi, Q.X.; Chen, W.Y.; Zhou, C.X.; Ni, Y.; Rowlands, D.K.; Yi Liu, G.; Zhu, H.; Ma, Z.G.; Wang, X.F.; et al. Cystic fibrosis transmembrane conductance regulator is vital to sperm fertilizing capacity and male fertility. Proc. Natl. Acad. Sci. USA 2007, 104, 9816-9821. [CrossRef] [PubMed]

92. Chen, W.Y.; Xu, W.M.; Chen, Z.H.; Ni, Y.; Yuan, Y.Y.; Zhou, S.C.; Zhou, W.W.; Tsang, L.L.; Chung, Y.W.; Hoglund, P.; et al. Cl- is required for $\mathrm{HCO}_{3}{ }^{-}$entry necessary for sperm capacitation in guinea pig: Involvement of a Cl- $/ \mathrm{HCO}_{3}{ }^{-}$exchanger (slc26a3) and cftr. Biol. Reprod. 2009, 80, 115-123. [CrossRef] [PubMed]

93. Lu, Y.C.; Chen, H.; Fok, K.L.; Tsang, L.L.; Yu, M.K.; Zhang, X.H.; Chen, J.; Jiang, X.; Chung, Y.W.; Ma, A.C.; et al. Cftr mediates bicarbonate-dependent activation of mir-125b in preimplantation embryo development. Cell Res. 2012, 22, 1453-1466. [CrossRef] [PubMed]

94. Chen, H.; Chan, H.C. Amplification of fsh signalling by cftr and nuclear soluble adenylyl cyclase in the ovary. Clin. Exp. Pharmacol. Physiol. 2017, 44 (Suppl. S1), 78-85. [CrossRef] [PubMed]

95. Lecuona, E.; Sun, H.; Chen, J.; Trejo, H.E.; Baker, M.A.; Sznajder, J.I. Protein kinase a-ialpha regulates na,k-atpase endocytosis in alveolar epithelial cells exposed to high $\mathrm{CO}_{2}$ concentrations. Am. J. Respir. Cell Mol. Biol. 2013, 48, 626-634. [CrossRef] [PubMed]

96. Sayner, S.L.; Frank, D.W.; King, J.; Chen, H.; VandeWaa, J.; Stevens, T. Paradoxical cAMP-induced lung endothelial hyperpermeability revealed by pseudomonas aeruginosa exoy. Circ. Res. 2004, 95, 196-203. [CrossRef] [PubMed]

97. Sayner, S.L.; Alexeyev, M.; Dessauer, C.W.; Stevens, T. Soluble adenylyl cyclase reveals the significance of cAMP compartmentation on pulmonary microvascular endothelial cell barrier. Circ. Res. 2006, 98, 675-681. [CrossRef] [PubMed]

98. Das, A.; Härtel, F.; Ihle, K.; Ladilov, Y.; Noll, T. Role of soluble adenylyl cyclase on barrier function of human umbilical vein endothelial monolayers: P21-13. Acta Physiol. 2016, 216, 216.

99. Di Benedetto, G.; Gerbino, A.; Lefkimmiatis, K. Shaping mitochondrial dynamics: The role of cAMP signalling. Biochem. Biophys. Res. Commun. 2017, 500, 65-74. [CrossRef] [PubMed]

100. Jayarajan, V.; Appukuttan, A.; Reusch, P.; Ladilov, Y.; Regitz-Zagrosek, V. Soluble adenylyl cyclase controls AMPK activity, mitochondrial function and biogensis and may play a role in estradiol-dependent protection against oxidative stress. In Proceedings of the 42nd FEBS Congress on Molecules to Cells and back, Jerusalim, Israel, 10-14 September 2017.

101. Kumar, S.; Kostin, S.; Flacke, J.P.; Reusch, H.P.; Ladilov, Y. Soluble adenylyl cyclase controls mitochondria-dependent apoptosis in coronary endothelial cells. J. Biol. Chem. 2009, 284, 14760-14768. [CrossRef] [PubMed]

102. Appukuttan, A.; Kasseckert, S.A.; Kumar, S.; Reusch, H.P.; Ladilov, Y. Oxysterol-induced apoptosis of smooth muscle cells is under the control of a soluble adenylyl cyclase. Cardiovasc. Res. 2013, 99, 734-742. [CrossRef] [PubMed]

103. Acin-Perez, R.; Russwurm, M.; Gunnewig, K.; Gertz, M.; Zoidl, G.; Ramos, L.; Buck, J.; Levin, L.R.; Rassow, J.; Manfredi, G.; et al. A phosphodiesterase 2a isoform localized to mitochondria regulates respiration. J. Biol. Chem. 2011, 286, 30423-30432. [CrossRef] [PubMed]

104. Hess, K.C.; Liu, J.; Manfredi, G.; Muhlschlegel, F.A.; Buck, J.; Levin, L.R.; Barrientos, A. A mitochondrial $\mathrm{CO}_{2}$-adenylyl cyclase-cAMP signalosome controls yeast normoxic cytochrome c oxidase activity. FASEB J. 2014, 28, 4369-4380. [CrossRef] [PubMed] 
105. DiPilato, L.M.; Cheng, X.; Zhang, J. Fluorescent indicators of cAMP and EPAC activation reveal differential dynamics of cAMP signaling within discrete subcellular compartments. Proc. Natl. Acad. Sci. USA 2004, 101, 16513-16518. [CrossRef] [PubMed]

106. Pozdniakova, S.; Guitart-Mampel, M.; Garrabou, G.; Di Benedetto, G.; Ladilov, Y.; Regitz-Zagrosek, V. 17ß-estradiol reduces mitochondrial cAMP content and cytochrome oxidase activity in a phosphodiesterase 2-dependent manner. In Proceedings of the 42nd FEBS Congress on Molecules to Cells and back, Jerusalim, Israel, 10-14 September 2017.

107. Wang, Z.; Liu, D.; Varin, A.; Nicolas, V.; Courilleau, D.; Mateo, P.; Caubere, C.; Rouet, P.; Gomez, A.M.; Vandecasteele, G.; et al. A cardiac mitochondrial cAMP signaling pathway regulates calcium accumulation, permeability transition and cell death. Cell Death Dis. 2016, 7, e2198. [CrossRef] [PubMed]

108. Mukherjee, S.; Jansen, V.; Jikeli, J.F.; Hamzeh, H.; Alvarez, L.; Dombrowski, M.; Balbach, M.; Strunker, T.; Seifert, R.; Kaupp, U.B.; et al. A novel biosensor to study cAMP dynamics in cilia and flagella. eLife 2016, 5, e14052. [CrossRef] [PubMed]

109. Acin-Perez, R.; Gatti, D.L.; Bai, Y.; Manfredi, G. Protein phosphorylation and prevention of cytochrome oxidase inhibition by atp: Coupled mechanisms of energy metabolism regulation. Cell Metab. 2011, 13, 712-719. [CrossRef] [PubMed]

110. Valsecchi, F.; Konrad, C.; D’Aurelio, M.; Ramos-Espiritu, L.S.; Stepanova, A.; Burstein, S.R.; Galkin, A.; Magrane, J.; Starkov, A.; Buck, J.; et al. Distinct intracellular sac-cAMP domains regulate er $\mathrm{Ca}^{2+}$ signaling and oxphos function. J. Cell Sci. 2017, 130, 3713-3727. [CrossRef]

111. De Rasmo, D.; Signorile, A.; Santeramo, A.; Larizza, M.; Lattanzio, P.; Capitanio, G.; Papa, S. Intramitochondrial adenylyl cyclase controls the turnover of nuclear-encoded subunits and activity of mammalian complex $\mathrm{i}$ of the respiratory chain. Biochim. Biophys. Acta 2015, 1853, 183-191. [CrossRef] [PubMed]

112. Sardanelli, A.M.; Signorile, A.; Nuzzi, R.; Rasmo, D.D.; Technikova-Dobrova, Z.; Drahota, Z.; Occhiello, A.; Pica, A.; Papa, S. Occurrence of a-kinase anchor protein and associated cAMP-dependent protein kinase in the inner compartment of mammalian mitochondria. FEBS Lett. 2006, 580, 5690-5696. [CrossRef] [PubMed]

113. Agnes, R.S.; Jernigan, F.; Shell, J.R.; Sharma, V.; Lawrence, D.S. Suborganelle sensing of mitochondrial cAMP-dependent protein kinase activity. J. Am. Chem. Soc. 2010, 132, 6075-6080. [CrossRef] [PubMed]

114. Valsecchi, F.; Konrad, C.; Manfredi, G. Role of soluble adenylyl cyclase in mitochondria. Biochim. Biophys. Acta 2014, 1842, 2555-2560. [CrossRef] [PubMed]

115. Lefkimmiatis, K.; Leronni, D.; Hofer, A.M. The inner and outer compartments of mitochondria are sites of distinct cAMP/PKA signaling dynamics. J. Cell Biol. 2013, 202, 453-462. [CrossRef] [PubMed]

116. Covian, R.; French, S.; Kusnetz, H.; Balaban, R.S. Stimulation of oxidative phosphorylation by calcium in cardiac mitochondria is not influenced by cAMP and PKA activity. Biochim. Biophys. Acta 2014, 1837, 1913-1921. [CrossRef] [PubMed]

117. Laudette, M.; Zuo, H.; Lezoualc'h, F.; Schmidt, M. EPAC function and cAMP scaffolds in the heart and lung. J. Cardiovasc. Dev. Dis. 2018, 5, 9. [CrossRef] [PubMed]

118. De Rasmo, D.; Micelli, L.; Santeramo, A.; Signorile, A.; Lattanzio, P.; Papa, S. CAMP regulates the functional activity, coupling efficiency and structural organization of mammalian fof1 atp synthase. Biochim. Biophys. Acta 2016, 1857, 350-358. [CrossRef] [PubMed]

119. Fazal, L.; Laudette, M.; Paula-Gomes, S.; Pons, S.; Conte, C.; Tortosa, F.; Sicard, P.; Sainte-Marie, Y.; Bisserier, M.; Lairez, O.; et al. Multifunctional mitochondrial EPAC1 controls myocardial cell death. Circ. Res. 2017, 120, 645-657. [CrossRef] [PubMed]

120. Pavlaki, N.; Nikolaev, V.O. Imaging of pde2- and pde3-mediated cgmp-to-cAMP cross-talk in cardiomyocytes. J. Cardiovasc. Dev. Dis. 2018, 5, 4. [CrossRef] [PubMed]

121. Monterisi, S.; Lobo, M.J.; Livie, C.; Castle, J.C.; Weinberger, M.; Baillie, G.; Surdo, N.C.; Musheshe, N.; Stangherlin, A.; Gottlieb, E.; et al. Pde2a2 regulates mitochondria morphology and apoptotic cell death via local modulation of cAMP/PKA signalling. eLife 2017, 6, e21374. [CrossRef] [PubMed]

122. Rinaldi, L.; Pozdniakova, S.; Jayarajan, V.; Troidl, C.; Abdallah, Y.; Muhammad, A.; Ladilov, Y. Role of Soluble adenylyl cyclase in reperfusion-induced injury of cardiac cells. Clin. Res. Cardiol. 2018. [CrossRef] 
123. Soares, L.M.; Meyer, E.; Milani, H.; Steinbusch, H.W.; Prickaerts, J.; de Oliveira, R.M. The phosphodiesterase type 2 inhibitor bay 60-7550 reverses functional impairments induced by brain ischemia by decreasing hippocampal neurodegeneration and enhancing hippocampal neuronal plasticity. Eur. J. Neurosci. 2017, 45, 510-520. [CrossRef] [PubMed]

124. Neviere, R.; Delguste, F.; Durand, A.; Inamo, J.; Boulanger, E.; Preau, S. Abnormal mitochondrial cAMP/PKA signaling is involved in sepsis-induced mitochondrial and myocardial dysfunction. Int. J. Mol. Sci. 2016, 17, 2075. [CrossRef] [PubMed]

125. Lezoualc'h, F.; Fazal, L.; Laudette, M.; Conte, C. Cyclic amp sensor EPAC proteins and their role in cardiovascular function and disease. Circ. Res. 2016, 118, 881-897. [CrossRef] [PubMed]

126. Khaliulin, I.; Bond, M.; James, A.F.; Dyar, Z.; Amini, R.; Johnson, J.L.; Suleiman, M.S. Functional and cardioprotective effects of simultaneous and individual activation of protein kinase a and EPAC. Br. J. Pharmacol. 2017, 174, 438-453. [CrossRef] [PubMed]

127. Zoccarato, A.; Surdo, N.C.; Aronsen, J.M.; Fields, L.A.; Mancuso, L.; Dodoni, G.; Stangherlin, A.; Livie, C.; Jiang, H.; Sin, Y.Y.; et al. Cardiac hypertrophy is inhibited by a local pool of cAMP regulated by phosphodiesterase 2. Circ. Res. 2015, 117, 707-719. [CrossRef] [PubMed]

(C) 2018 by the authors. Licensee MDPI, Basel, Switzerland. This article is an open access article distributed under the terms and conditions of the Creative Commons Attribution (CC BY) license (http:/ / creativecommons.org/licenses/by/4.0/). 